\title{
United States War on Terror in the Middle East and Afghanistan: A Critical Assessment
}

\author{
Yakubu Haruna Ja'e \\ Department of Political Science, Kaduna State University, Kaduna. \\ P.M.B 2339 Tafawa Balewa Way, Unguwan Rimi Kaduna, Nigeria
}

\begin{abstract}
Terrorism has become a serious problem to both domestic and International Security. The emergence of terrorist groups and individuals operating in the Middle East is worrisome. As a result this research aimed at finding out about the real causes of terrorism in the Middle East, the United States policies on combating terrorism and their implication to world security. The research uses Secondary Source of data to $d$ well on pure content analysis; the research uses available books, Videos and Documentaries on War on Terror in the Middle East. The theory adopted was rational comprehensive model of decision making theory which assumes that decision makers set their goals, evaluate their relative importance, calculate the cost and benefits of each possible course of action then choose one with the best benefits and less cost. The research posits that: the current United States policies on war on terror in the Middle East is too militaristic, and therefore can never end terrorism in the region. The United States Policy on War on Terror is decorated with Media Control, Propaganda, Covert Operations, torture, Manipulations and Intimidations. It has also been shown that the onesided support of Israel by United States government against Palestinians, Support of Arabs despotic and undemocratic rulers, United States invasion of Iraq and Afghanistan on reasons best known to them are all responsible for breeding new terrorists against United States and her core allies.
\end{abstract}

Keywords: Terrorism, Middle East, United States, Iraq, Afghanistan

\section{Brief Introduction}

The United States policy on war on terror was triggered by the September 11, 2001 attack on the USA by terrorists backed by Al-Qaida. The success of the attack was a blow on the United States Security System. President George W. Bush, the then President of United States of America vowed to launch a total war on terror by engaging United States forces in the Middle East and Afghanistan. Ten years after has this policy yielded any result? Why is it that terrorism is still prevailing in the Middle East and Afghanistan? Is the strategy used by the USA to combat international terrorism adequate? George W. Bush the initiator of the war on terror had not given us a scenario of how the war on terrorism will be fought over the years, and how we can sense whether America's strategy is following the right path.

\section{1:1:2 Reseach Questions}

This research therefore has the following as research questions;

i Why do terrorist groups and individuals from the Middle East attack United States frequently?

ii Can the current US policies on war on terror in the middle east be achievable or winnable?

iii What are the implications of US war on terror in the middle east?

iv Is the United States policy on War on Terror in the Middle East rational?

\section{1:1:3 Propositions}

This study has the following as propositions;

i The US war on terror in the Middle East breeds new terrorists.

ii The present policy of United States war on terror cannot end terrorism in the Middle East.

iii The implication and the nature of the US foreign policy in the Middle East is responsible for the terrorists attack on the United States.

iv. United States War on Terror is not rationally based.

\section{1:1:4 Theoretical Frameworks}

According to (Morgenthau, 1950) "A theory must be judged not by some preconceived principles or concept unrelated reality, but by its purpose to bring order and meaning to the mass of phenomena. Without this a theory may just be non- coherent and meaningless." For effective assessment of United States foreign policy on international terrorism in the Middle East,this research adopts rational comprehensive theory which also known as the rational model of decision making theory. Decision making analysis denotes an attempt to 
understand politics as a process of arriving at decisions. It is an analytical concept which involves a set of questions or categories in the light of which concrete institutional realities can be identified, described and compared (Macridis, 1961). It is a social process that selects alternatives for implementation and execution from among the many that may be available. It denotes the dynamic process of interaction among participants who determine particular policy choices, as observed by (Ray, 2003).This theory assumes that decision makers set their goals, evaluate their relative importance, calculate the costs and benefits of each possible course of action, then choose one with the best benefits and less cost. The theory as captured by (Ray, 2003), is to be distinguished by policy - making. Decision making is confined to choices that involve conscious action and are subject to sanctions.

For (Lasswell, 1965), he identifies seven functional stages through which all decisions are processed namely; information, recommendation, prescription, invocation, application, appraisal and termination. (March and Simon, 1957) who are closely associated to the theory distinguished four processes namely: problem solving, persuasion, bargaining and "politics". March and Simon, 1957) argued that: as a decision-maker operating according to this model (rational model), you should consider the following:

- Clarify your goals in the situation

- Order them by importance

- List the alternative for achieving your goals

- Investigate the consequences of each alternative.

- Choose the alternative that best achieves your goals at the least cost.

The theory is relevant because it will help us to analyze the rationality of US policy Makers in fighting a War on Terror in the Middle East.

\section{1:1:5 Defining Terrorism: The Controversial Term}

Both government and individual researchers varied tremendously in defining the word 'Terrorism'. The incidents to be considered terrorism have also varied. To the United States whenever she attacked a sovereign government or individual, she is defensive rather than offensive and she is never a terrorist or offensive. On the other hand, the states and groups alleged to be terrorists by the United States the reverse is the case. Terrorism is notoriously difficult to define because it is associated with an activity that is designed to be subjective.

Specialists in the field of terrorism studies have developed hundreds of pages towards trying to develop unassailable definitions of the term 'Terrorism'. Thus, the term is seen differently by different scholars. To (Andrey, 2003) "Terrorism is the threat or use of seemingly random violence against the innocents, for political ends by a non state actor". This definition never identifies states to be engaged in terrorist acts which are fallacious. The statue of the United States court section 2656f (d) the (United States Department of State, 1996) contains the following: "The term terrorism means pre-mediated, politically motivated violence perpetrated against non combatant target by sub- national groups or clandestine usually intended to influence an audience". Also in the same version, the FBI release (1999) defines international terrorism as:

"The unlawful use of force or violence committed by groups or individuals who has some connections to a foreign power or whose actives transcend national boundaries against persons or property to intimidate or coerce government, the civilian population, or any segment thereof in furtherance of political or social objectives".

In another point of view (Crozier, 1960:159) argues that: "Terrorism is the threat of use of violence for political ends. Whereas, (Malison, 1976:) defines terrorism as 'the systematic use of extreme violence and threat of violence in other to achieve public objectives'. This definition resembles that of (Moss, 1971:1) which says terrorism is "the systematic use of intimidation for political ends". Terrorism is also considered by some to be 'a form of war without the conventional conflicts' (Jamieson, 1995). These definitions have several common things and meanings, in that they all distinguish between actions and threats, and they all stress the idea of the systematic use of force, threat or violence. There is also a general agreement that terror introduces into the political process varying degrees of elements of reactions, fear, anxiety, disorientation and disorganization as noted by (Vangh, 1978).

On the other hand, (Albert, 1976) sees terrorism as essentially a ferocious violence of humans against humans. In order to test the applicability of these several definitions and generalizations to the Middle East more distinctions are needed both governmental and nongovernmental towards the end of this work. It is important to be in our note that terrorism are of various types as (Michael,1979) identified three forms of terrorism viz; Transnational or International terrorism which is carried out by Government or individuals across borders, Domestic terrorism: this is violence by individuals that do not involve nationals of more than one state, State terrorism: this according to him involves terrorists actions conducted by a national government within the borders of that state, and is the domestic parallels of international terrorism. Furthermore, as the types of Terrorism differ the Tactics and incidents also vary. (Edward, 1979) identified some tactics which are; 
Kidnappings, Bombings, Letter Bombs, Barricades and hostages, Armed Attacks, Takeovers, Skyjackings, Arsons, Murders and Assassinations, Sabotages and theft or Break-in

\section{1:1:6 An Overview Of Causes Of Terrorism}

The reasons behind terrorisms are diverse as the types of people who commit terrorist attacks. (Wolfohson, 2002), identified the following as the cases of terrorism;

(a) Inequitable or at least perceptions of inequitable or repressive internal and external power structures resulting in the marginalization of individual groups and nations on the basis of ethnicity, religion, identity, and ideology. (b) Oppression by a majority of a minority, or by a minority thereby generating feelings of hopelessness.

(c) The struggles of the minorities over ideological problems and also with the purpose of acquiring political rights, self determination or independence.

(d) Extreme socio-economic factors marked by abject poverty, unemployment, and conscious affluence to a ruling class.

(e) Poor and corrupt governance, illiteracy, ignorance, lack of skilled education and awareness which leads to widespread ignorance about the modern world and the western values.

(f) The rise of Islamic conservation, fundamentalism and even extremism. All these are the causes of terrorism.

If really it is poverty, unemployment, Extremism, Economic backwardness and uncivilisation could cause terrorism as noted by (Wolfehson, 2002) then, how do the terrorist manage to survive in a jungle? How do they manage to attack the most powerful state on earth (US) that possesses all sought of sophisticated weapons? Why committing suicide attacks with their expensive vehicles? How and why did the current war on terror become unwinnable? This research will therefore, find answers to these questions.

Chomsky(2001)On the other hand argued that Americans have a history of buying targets of terrorists' attacks and this has largely been attributed to the US Foreign Policy, particularly, with regard to the Middle East and the Israel-Palestinian conflict, and their military interventionists' policies in many part of the world (Yakubu, 2012) admitted that, all these have caused widespread resentment toward US. To (Salamatu, 1999) the main cause of terrorism is the dissatisfaction with the political or social system or policy and the inability to change it through 'mainstream' or non violence means. There must be political, social, ethnic or religious creed to justify it. Religious segregation, political injustice and resistance to military occupation are the most often cited reasons behind terrorism (Fadllallah 2002:1 Quoted from Haruna, 2006).

\section{1:1:7 How The United States Policy Breeds Terrorism In The Middle East}

The following served as the reasons why the US war on terror at present if not change, will only breed new terrorists, and the target of the US in particular and the world at large to end terrorism will be fruitless and unachievable.

\section{(a)The United States Scandals in Abu Ghuraib Prison}

No doubt, the United States detainees in Abu Ghuraib (Iraq) were humiliated intimidated and harassed. When one search for their images on the net, one will definitely believe that the US is causing terrorism by fighting terrorism. Out of the interlocking scandals and controversies symbolized by hooded man and Leashed Man, the pyramids of naked bodies of Iraqis women, children and old men, the snarling dogs. One image was shown on Google, where an Arab man was naked, lying at the feet of a short-haired American woman. In camouflage garb, who stares immodestly at her Arab pet while holding him by the throat with a leash. Those images shocked Iraqis and the entire Arab countries about how the U S is maltreating them. The U S policy of dealing the Abu ghuraib inmates in the name of 'war on Terror' was a total failure that can only breeds new terrorists in the Middle East who will continue to target United States and her core friends.

The Abu ghuraib United States' torture began in 2004. It accounted of physical, psychological and sexual abuse, including torture, rape, sodomy and homicide of prisoners held in the Abu ghuraib prison in Iraq. These acts were committed by Military Police personnel of the U S army together with additional US governmental agencies. Major General Antonio Taguba of the United States has aknowlged that; there is a photographic evidence of rape being carried out by American Military Personnel of Abu ghuraib. An Iraqi teenage boy was raped by a uniform man while photos of it were taken by a female US Military Police. The alleged rapist was identified by a witness as an American. Another photo shows an American soldier apparently raping a female prisoner. Other photos show sexual assaults on prisoners with objects including a truncheon, wire and a phosphorescent tube, and a female prisoner having her clothing forcibly removed to expose her breast. www.google/abughuraibtouture.com

To show how the US tortured Abu ghuraib prisoners evidently, the US times of January 12, 2005 (Quoted from Haruna, 2004) reported testimony suggesting that the following events had really taken place in the Abu ghuraib Prison.

Urinating on detainees 
- $\quad$ Jumping on detainees leg (a Leg already wounded by gun fire) with such force that it could not thereafter heal properly.

- $\quad$ Continuing by pounding detainee's wounded legs with collapsible metal baton.

- $\quad$ Pouring phosphoric acid on detainees

- $\quad$ Sedomization of Arab detainees with a baton

- $\quad$ Tying ropes to the detainees' legs or penises and dragging them across the floor.

The following is an account of what the US soldiers did to Abu ghuraib prisoners by some of the prisoners themselves from a video diary.

HashlemMuhsen a prisoner, and one of the naked men in the human pyramid photo said

"Prisoners were shot dead for minor misbehavior, and claimed to have had venomous snakes bite in sometimes resulting in their deaths, sometimes throwing rocks on the detainees, he added that they were also made to crawl around the floor naked and that US soldiers rode them like donkeys".

Amen Saeed Al-shaikk a detainee No 151362, Narrated that;

"The United States prisoners guard said to us, "we will make you wish to die and it will not happen... they stripped me naked: He added one of them told me he would rape me. He drew a picture of a woman to my back and made me stand in shameful position holding my buttocks". He also added that: they once asked him "Do you pray to Allah? Yes. They said, (Expletive) you. And expletive him 'one of them said, 'you are not getting out of here healthy, you are getting out of here handicapped. And he said to me, are you married? I said yes, they said, if your wife sees you like this, she will be disappointed. One of them said: "But if I saw her now she would not be disappointed now because I will rape her" I said to him I believe in Allah: So he said, but I believe in torture and I will torture you!

To sum up, most Iraqis and other Arabs in the Middle East said that an apology is not enough of the future of Iraqi prisoners, and as such the US should get ready for more terror of Iraqi prisoners and as such the US should get ready for more terror act.

\section{(b)The United States Action Over September 11, 2001 Attack}

No doubt that, the aftermath of Sept. 11, bomb attack on US WTC and the Pentagon has really prompted a new line of study and thought in relation to terrorism and counter terrorism. Hundreds of speeches, articles and books were written regarding Sept/11 and the US action concerning the event. Most of the writings expose how America and its foreign policies especially on war on Terror become inimical to the interest and well being of other nations (Middle East in particular). A week after the Sept. 11, 2001, tragedy George W. Bush, the US President addressed his congress. He has the following as the address:

"Americans are asking, "Why do they hate US?" They hate what they see right here in this chamber a democratically elected government. Their leaders are self-appointed. They hate our freedoms" (Abu Umar, 2004)

It is evident, that the whole world rose in condemnation of WTC and Pentagon attack of September 11, 2001. Some countries even in the Middle East termed it as dastard act and therefore called for justice. Events however took a new turn immediately. The press (especially the western), the American security network and notably politicians came out hard on the Muslims and the US President; George W. Bush fluidly accused AlQaida to be responsible and declared a crusade (Abu Umar, 2004). In his address at the United States Congress President G. W. Bush has the following:

"Our war against terror is only beginning, Iraq continues to plan hostility towards United States of America to support terror, the Iraqi regime has planned to develop nuclear weapons for over a decade. This is a regime that has something to hide in a civilized world, a state like this will constitute an act of evil to threaten the peace of the world by seeking weapons of mass destruction; this regime is causing a grieve and danger...'(Quoted from Abu Umar, 2004)

It was not for the first time the US government is misinforming the world about a particular event. The Oklahoma bombing was one instance where those involved in the terror act were concealed and others were wrongly and deliberately held responsible. The September 11, 2001 bombing of the WTC and the pentagon was explained as a pretext and a deliberate attempt to cause grief, suspicion and danger by the US under Bush administrator. The US without any proof continues to shout that Usamabn laden of Al-Qaida group is responsible for the attack, this led United States government to attack Afghanistan in the name of "war on terror". Hundreds of researchers have proved it since that Usama bin laden is not responsible, rather it is an internal attack that is home made.

In a documentary tagged September 11, produced by Korey Rome, written and directed by Dylan Avery, about $90 \%$ of Americans believe that September 11, was an inside job (done by US government). According to the US national poll regarding September 11, in which Americans were asked "Do you believe that there is a United State government cover-up surrounding 9/11? 7747 people out of 8582 that voted (90\%) 
against $835(10 \%)$ believed that $9 / 11$ was an inside job. Unfortunately, the western media continue to debunk it and held Usama bin laden to be responsible. It was reported that half of the Americans living in New York's believe that the United State leaders had a fore knowledge of impending 9/11 attack and constantly failed to act. Few hours after the attack, the then US National Security adviser Condoleezza Rice was quoted saying "I don't think anybody could have predicted that 'these people' would take an air plane and slain it into WTC". While Donald Ramsfeld, US defense secretary then, in his comment said "There were lots of warnings". But deliberately no action was taking to stop it because it was a pretext.

Richard Clarke, White House adviser says "your government failed you (Americans) and I failed you". To evidently, show that some US officials were engage and aware of the attack before it took place. It was documented in the documentary " $9 / 11$ " by Korey (et al) that on 10/September/2011 a day to the bombing "Top Pentagon officials cancel flights", San Francisco Mayor WillerBowngot early warnings about air travel on the day of $9 / 11$ " Similarly, to testify that it was a deliberate set up or cover action, some explosives were planted in the WTC before the plane crash. Don Perked MSNBC was quoted saying that:

“...even before stepping outside I could smell the cordite I knew explosives had been set off somewhere..."

Furthermore, it should be noted that research has shown that, on the day of the attacks, former Israeli Prime Minister Benjamin Netanyahu was asked what the attack would mean for US - Israel relationships. His quick reply was "It's very good, well, it's not good, but it will generate immediate sympathy for (Israel). New York Time (September 12, 2001). According to ABC's 20/20, some five Israeli agents were caught after the attack in a Van belonging to the cheering Israelis which was stopped by the Police; the first words out of the driver's (Sivan Kornberg) mouth were problems".

"We are Israelis, we are not your problem. Your problems are our problems. The Palestinians are your

A few days after the attacks, urban moving system Israeli owner, Dominick Suter, dropped his business and fled the country. He was in such a hurry to flee America that some of urban moving systems customers were left with their furniture stuck in storage facilities. The fire Israeli army veterans (mossad) were held in custody for several months before being quietly released. Some of the movers had been kept in solitary confinement for 40 days" (Abu - Umar: 2004: $24-25$ ).

Despite all the above aforementioned deviances, the US continues to hold Al-Qaida responsible. Some Arabs from Middle East four of them from Saudi Arabia were blacklisted as the hijackers of air planes on 9/11, one of them had never been to United States but United States FBI included his name as a terror responsible for September 11 .

According to the Telegraph of England of September, 23, 2001:

"Their names were flashed around the world as suicide hijackers who carried out the attacks on America. But yesterday four innocent men told how their identities had been stolen. The men - all from Saudi Arabia spoke of their shock at being mistakenly named by the FBI as suicide terrorists. None of the four was in the United States on September 11 and all are alive in their home country. The Telegraph obtained the first interviews with the men since they learnt that they were on the FBI's list of hijackers who died in the crashes in New York, Washington and Pennsylvania. All the four said that they were outraged to be identified as terrorists. One has never been to America and another is a Saudi Airlines pilot who was on a training course in Tunisia at the time of the attacks".

To cut the enormous evidences short, here are the summary of the facts that the Bush administration is very much aware that it is not Al-Qaida, or Usamabn laden that was responsible for the attack, rather it was planned, organized and carry out by Israelis to make it looks like a Palestinian or Arab act. Below are the summary of the factual points as itemized by (Umar, 2004. 126-127).

* There was absence of 4000 Jews from work at the time of the attack. (Reported by Newsbytes/Washington Past) by Brian Mc Williams 27 September 2001.

* The role of the media employing the instrument of repetition to aggregate the anger of Americans against the supposed perpetrators; remember operation Northwood "Casualty list in US newspapers would help course a move of national indignation" (Herman, 2001).

* The immediate declaration by the perpetrators (American government and Jewish allies) of war and the call for a United front (The NATO Alliance).

* The US declaration that the war on terror would be global. It won't be restricted to the perpetrators alone but to all those who bear similar traits.

* The American government decision to ignore the call (by David Duke and a like) to investigate the Jewish connection.

* The looking up of baseless evidences that were refuted.

* The onslaught despite the lack of evidence. 
* The declaration that no distinction would be made between the so-called terrorists and government harboring them.

* The deliberate use of the media in diverting the world away from evidences to the battle field, and reaching that it is war against terror not against Islam.

* The refusal of the US government to denounce fighting Afghanistan in the name of fighting terrorism despite all evidences (by the Americans and others) that proved them innocent (Harun, 2004:127)

\section{(C) American Invasion Of Afghanistan}

It was revealed long before by the former foreign minister of Pakistan, NiazNaik who commented on the intention of the American government to eliminate the Taliban's before September 11, attack, as he said this was how he put it:

"The Americans indicated to us that in case the Taliban does not behave and in case Pakistan also does not help US to influence the Taliban, then the United States would be left with no option but to take an overt action against Afghanistan, during the "6 plus 2" meeting in Berlin July 2001, the discussions turned around "The formation of a government of national unity.

If the Taliban had accepted this coalition, they would have immediately received international economic aid and the pipe lines from Kazakhstan and Uzbekistan would have come'. Naik also claimed that Tom Simons, the US representative at these meetings openly threatened the Taliban and Pakistan. In his words, Simon said, either the Taliban behave as they ought to, or Pakistan convinces them to do so, or we will use another option. The words Simons asked were 'a military operation'. Furthermore, he states at one moment during the negotiations, the US representatives told the Taliban, "either you accept our offer of a carpet of gold, or we bury you under a carpet bombs", quoted from (Haruna, 2004: 127).

Perhaps, that was why the US government under President Bush attacked Afghanistan in search of AlQaida and other Terrorist groups (named by the US) in connection with September 11, attack. The invasion of Afghanistan by the US government in 2001 has no doubt been interpreted by many Muslims especially in the Middle East, North Africa and part of Europe to be 'War on Islam' an interpretation that US government failed to debunk and convince the world that it wasn't a War on Islam (Harun, 2004).Robert Byrd, the oldest senator in the US congress, who was a closed friend to the President Bush the senior, argued that:

"The Afghan war is a Dog". He said "We (Americans) are spending $\$ 100,000,000,000.00$ (100 billion) on a country which has a GDP of $\$ 1.4,000,000,000.00$ (14 billion). It is like' buying a $\$ 14,000.00$ very badly maintained used car for $\$ 100,000.00$ I would say that the Narco-Kleptocracy of the Karzibrother's et al really got a good deal. They want US there so there so they can steal more".www.davidduke.com/robertbyrd

David Duke a onetime US Senator observed that:

"I wonder what the kill ratio is in Afghanistan. Perhaps one member of the Al-Qaida network is killed for every 10 run-of-the mill Afghan soldier and civilians who are basically just trying to get through their own lives like the rest of US. Or may be like 1 terrorist for a 100 Afghanis. I suspect the real figure is more like a 1000 non-terrorists dead for the life of 1 genuine terrorist who might ever bother America".www.davidduke.com

No doubt, the action took by Bush administration on attacking the innocent Afghan government has significantly lead to persistent increase of "hating the American government" it only breeds new terrorists ready to revenge.

\section{(D). United States Invasion Of Iraq}

Few years after American invasion of Afghanistan, the same United States during President Bush invaded Iraq on false reasons of war on terror and disarming Iraq from nuclear arms. Robert Byrd, the oldest senator in United States, once made this speech in US congress:

".....To contemplate war is to think about the most horrible of human experiences. On this February day, at this notion stands at the brink of battle, every American on some level must be contemplating the horrors of war.....Yet, this chamber (American) is for the most part, silent ... ominously dreadfully silent. There is no debate, no discussion, no attempt to layout for the nation the pros and cons of this particular war. There is nothing...."We stand passively mute in the United States senate, paralyzed by our own uncertainty; seemingly stunned by the sheer turmoil of events........ This nation is about to embark upon the first test of a revolutionary doctrine applied in an extraordinary way at an unfortunate time. The doctrine of preemption... the idea that the United States or any other nation can legitimately attack a nation that is not imminently threatening but may be threatening in the future... is a radical new twist on the traditional idea of self defense. It appears to be in contravention of international law and the UN charter...."

This speech was delivered by a US Senator who was not on the opinion of US invasion of Iraq on false reasons of war on Terror and WMD. Few years after US attack on Afghanistan, Iraq was attacked by the same 
US government in the name of fighting terrorism. President G. W. Bush, in order to legitimate his war on Iraq few days before the war begins he says to his countrymen, I quote:

"The dangers to our country (US) are growing, Saddam Hussain posse's biological and chemical weapons... according to British government, Iraq regime can launch a biological or chemical attack in at least 45 minutes ... the regimes continue to ties with terrorist organizations, and there are alongside terrorist inside Iraq, the regime is seeking a nuclear bomb..." (Documentary: uncovered the whole truth about Iraq war by Cote et al)

After Bush's "convoluted reasons" as said by Senator Byrd, a former White House Counsel John Dean commented that "Bush presented so many distorted beliefs... the opinion is misleading the public and the congress..." In the New York Times on October 10, 2002, Senator Bryd wrote:

"... Are we too feeble to resist the demands of a president who is determined to bend the collective will of congress to his will - a president who is changing the conventional understanding of the term "self defense"? And why are we allowing the executive to rush our decision -making right before an election? Congress, under pressure from the executive branch, should not hand away its constitutional powers. We should not hamstring future congress by casting such an over sighted vote. We owe our country a due deliberation..." He aptly defined Bush as phony and knew that like five determent Cheney, Bush was a coward" He concluded.

David Duke a one time member of the US congress argued that:

"The war on Iraq was an immoral, hypocritical - war, a war fought for Israel and against every vital interest of the United States of America. It was a war that simply could not have been possible without the Jewish supremacist domination of both the government (of US) and the media".

A Dossier of civilian Causalities' in Iraq 2003-2005 available in www.jstor.org reported 42,500 civilians were wounded, 24,856 civilians were killed about $20 \%$ of all the civilians death were women and children all in the first two years alone.

It is evident and apparent that, the way United States dealt with Sadam's regime "hypocritically" cause more terrorists in the Middle East. The invasion of Iraq is a cause of breeding new terrorists in the region and the US war on terror will be fruitless and endless. David Duke once asserts that

"We (American government) dropped more explosives on Iraq in a few weeks than we had in the whole of the Second World War. We killed hundreds of thousands of Iraqis including tens of thousands of civilians. Then we engaged in a blockage and embargo of Iraq that even the anti-Iraq United Nations says led to the deaths of at least 1,200.000 children and hundreds of thousands of elderly. Let those Americans who don't understand the why of this terrorism concentrate on this shocking fact. One million, two hundred thousand children have died as a direct result of our policy toward Iraq: and some Americans wonder why we are so hated?". David Duke (2005).www.davidduke.com

Senator Byrd, lamented that:

"Bush's war in Iraq was abysmal failure, to put it kindly. It has killed and maimed hundreds of thousands of Iraqis and thousands of coalition soldiers. It has pitched clan vs clan, tribes vs tribes and brothers vs brothers in a country that was actually very 'stable and safe'... did the people of Iraq deserve the death carnage and destruction that we brought to them"?

Therefore to cut it short, since the aim is to show how US is breeding new terrorists not to talk about US Iraq war in particular. It is evident that United States invasion of Iraq in the Middle East is another factor that will continue to make "US war on terror" endless and fruitless.

\section{(E). United States Support Of Israel Against Palestine}

The former Israeli Prime Minister Aerial Sharon: once said in a fit of anger.

"Every time we do something you tell me America will do this and will do that... I want to tell you something very clear: don't worry about American Pressure on Israel. We, the Jewish people, control America, and the Americans know it". Sharon's response to a Hebrew Israeli radio station, Kol Israel, an argument in an Israeli cabinet meeting, Shimon Peres warned the Prime Minister (Daniel Sharon) that unless he would heed American requests for a cease fire with the Palestinians, he could cause America to turn against Israel. Quoted from (Umar, 2004:22)

It is undebatable that, United States foreign policy in the Middle East is centered on her interest and the interest of her core ally (Israel). The so called terrorists in the Middle East have been saying often and often that the US support of Israel against Palestinians is annoying them.

When Bin laden was interviewed by a reporter, John Muller of ABC in May, 1998, Bin laden talks about why he seeks to attack America. He says:

"For over half a century, Muslims in Palestine have been slaughtered and assaulted and robbed of their honor and of their property. Their houses have been blasted, their crops destroyed..." This is my message to the American people: to look for a serious government that looks out for their interest and does not attack other 
people's kinds, or other people's honor. And my word to American journalists is not to ask why we did that but ask what their government has done that forced us to defend ourselves..."

"So we tell the Americans as people and we tell the mothers of soldiers and American mothers in general, that if they value the lives and the lives of their children, to find a patriotic government that will look after their interests and not the interests of the Jews...

I say to them that they have put themselves at the mercy of a disloyal government, and this is most evident in Clinton's administration (George W. Bush) represents Israel inside America. Talk the sensitive ministries such as the secretary of state and the secretary of defense and the CIA, you will find that the Jews have the upper hand in them. They make use of America to further their plans for the world...".

David Duke the National President of Euro, in his writing tagged "The big lie" lamented that:

"Bin laden never did not say one word about opposing democratic principles nor has he ever done so in his life time. He attacks US not because he hates democracy, but because he thinks Israel controls and uses America to attack his people..."

Israeli - Palestinian crises that is the longest crises in the world is really a factor that is playing role in breeding new terrorists in the Middle East. This is because Israel supported by US has been securely brutalizing and dehumanizing Palestinians - with sophisticated weapons majorly provided by the US. Despite all the brutal terrorists act cause by Israel, US continue to identify Israel as 'most peaceful country in the region' and therefore continue to support and back Israel financially, politically and even militarily. Stauffer is a Washington; D. C. based engineering economist cost alone of instability and conflict in the region - which emanates from the core Israeli Palestinian conflict. He says "Total identifiable costs to almost $\$ 3$ trillion and that about $60 \%$ well over half, of these costs about $\$ 1.7$ trillion arose from the US defense of Israel, where most of that amount has been incurred since 1973. He added that; Support for Israel comes to $\$ 1.8$ trillion including special trade advantages, preferential contracts, or aid buried in other accounts. In addition to the financial outlay, US aid to Israel costs some 275,000 American jobs each year. The trade aid imbalance alone with Israel of between $\$ 6-10$ billion costs about 125,000 American jobs every year. In another counter report by www.wrmca.com, currently the financial aid stands at $\$ 88.2$ billion it only reflects the minimum, as it does not include the many hidden costs.

Mc Arthur's article (2002) available at above web maintained that in 2002 alone Israel received \$ 5.45 billion in defense department funding. A research conducted by congressional research service (2010) reports indicates that Israel has received $\$ 42$ billion in waived loans. United States Support for Israel has cost America dearly well over than $\$ 10,000$ per American. According to Staffer, the total bill for supporting Israelis two to four times higher than that for the US alone is costing the global community an estimated $\$ 6$ to $\$ 12$ trillion.

It is evident, that Israel possesses most sophisticated weapons in the Middle East including nuclear weapon all with the support of United States. Part of the reasons why Iraq and Iran were named as terrorists sponsors by the US government's blacklist, was their (Iraq, Libya, Iran, North Korea etc) attempt to possess the same weapons to defend their territories. United States being the world supper power, and the closed ally of Israel hypocritically, and discriminately became one sided in her foreign policies towards Middle East. This factor alone is a tragedy to US war on terror; and the more the US continue to support the injustice of Israel in the region, the more it creates hundreds of enemies that would hate American's as rightly observed by (David,2002).

\section{Conclusion}

The meaning of terrorism according to the USA is totally confusing, and misleading as shown right from the introduction of this study. The measures employed by United States government to fight terrorism itself need to be changed otherwise it will only expose United States and its allies to danger and war. The role United States played in Abu Ghuraib Prisons, United States invasion of Iraq and Afghanistan after September 11, 2001 attack, Support of Undemocratic rulers in the Middle East, One-sided Support of Israel against Palestinians are responsible for the failure of US 'War on Terror' The Militaristic Policies if not soften will only breed new terrorists against the United States.

\section{References}

[1]. Albert, Perty. (1976) Terrorism from Robespierre to Arafat. The Vanguard Press Inc, New York.

[2]. Allison, Jamieson (1995) Terrorism. New York: Thomson Learning Press.

[3]. Brian Mc Williams. (2001) “Instant Message to Israel Warned of WTC attack”, The Washington Post Report.September 27 ${ }^{\text {th }}, 2001$.

[4]. BBC News October $25^{\text {th }}, 2001$.

[5]. Chomsky, N (2001) 9/11. New York; Steven Stories Press.

[6]. Crozier, B (1960) The Rebels: A study of Post-War Insurrections. Boston: Beacon Press. P. 159.

[7]. Chris, K. (2001). "Week One: Operation infinite Disaster" in Common Dreams. October 16 ${ }^{\text {th }}$, 2001. www.commondreams.org.

[8]. Duke, David htt;// davidduke.com

[9]. $\quad$ FBI release 1999

[10]. Edward, C (2004)“Iraqi's contempt for troops on Display”, Washington Post June $12^{\text {th }}, 2004$. 
[11]. Greenwald, R. Kate, M. C. and Smith, D (Producers) Robert, G (Director) (2004). Uncovered: the whole Truth about Iraq War. Center for American Progress. United States. www.centerfor americanprogress.org

[12]. Lasswell Harold (1965). The Decision Process. College Park; University of Maryland.

[13]. Haruun, A (ed) (2004) September 11 Before and Beyond. Lagos: Muslim Press International.

[14]. Haruna, Y (2006) United States Foreign Policy and International Terrorism: A study of Palestinian Crisis (2000 - 2005) Unpublished BSc Project, ABU Zaria.

[15]. htt://www.wrmca.com

[16]. htt://www.google/abughuraibtorture.com

[17]. htt://www.antiwar.com/photos/perm/ag21.jpg

[18]. htt://www.jstot.org/robertbryd.org

[19]. MallisonW.T, andMallison, S.V. (1976) "The Concept of Public Purpose Terror in International Law" The Journal of Palestinian Studies. Vol4, No 2, p. 36

[20]. Moss Robert (1971). "Urban Guerillas war fair”, Adalphi Papers No 79.Bostorn Beacon Press: New York.

[21]. Morgenthau, H. J (1992) Politics among Nations. New York; Alfred A Knopt

[22]. Ray S. N (2003) Modern Comparative Analysis: Approaches, Methods and Issues. New Delhi; Prentice Hall of India.

[23]. Robert G (Producer) Uncovered the whole truth about Iraq War (Motion Picture) available at www.centerforamerican progress.org

[24]. Robyn Dixon in Barji "living with war: dying a way of like for civilians in Afghanistan" Los Angeles Time. November 19, 2001

[25]. Salamatu, Umar.(1999) Terrorism in International Politics: Usama Bin Laden Versus United States of America.(Unpublished MIAD Thesis) Department of Political Science, ABU, Zaria

[26]. The Telegraph of England. September $23^{\text {rd }}, 2001$

[27]. The United States Times. January $12^{\text {th }}, 2005$.

[28]. The New York Times. November $2^{\text {nd }}, 2001$.

[29]. United States Department of State (1996) Stature of the US Court Section. 2656F (d)

[30]. Umar A.A(ed) (2001) Will Any One Dare Ask Why America Why? Lagos; Sal Sabil Associates.

[31]. Wolfehson J. D (2002) "Fight Terrorism by Ending Poverty."News Perspective: Blackwell Publishers.

[32]. www.google/abughuraibtouture.com 